\title{
Attitudes of Prospective French Teachers Towards School Experience and Teaching Practice Courses
}

\author{
Zuhre Yilmaz Gungor, Assist. Prof. Dr.
}

Anadolu University, Turkey

Doi:10.19044/ejes.v8no4a65

URL:http://dx.doi.org/10.19044/ejes.v8no4a65

Submitted: 24 August 2021

Accepted: 06 December 2021

Published: 31 December 2021
Copyright 2021 Author(s)

Under Creative Commons BY-NC-ND

4.0 OPEN ACCES

\begin{abstract}
Education is an important concept that prepares society for change and pushes development. The teacher, who is one of the basic elements of the education phenomenon, has important duties. Accordingly, the teacher has a very important place in the life of the students. The aim of this study is to determine the attitudes of the prospective French teachers towards School Experience and Teaching Practice courses and to reveal whether their attitudes differ according to the gender factor. The research has been conducted by means of a descriptive survey model and was carried out with the participation of 18 volunteer students (10 females, 8 males) studying at the department of French Language Teaching of the Faculty of Education at Anadolu University. The quantitative data of the study has been collected with a 5-point Likert-type scale consisting of 30 items. Moreover, in addition to the scale, the opinions of the students on the School experience and Teaching Practice courses have been collected by means of 5 open-ended questions drawn up by the researcher. The qualitative data acquired in this study has been reviewed through the document analysis method. According to the obtained data, it has been determined that the students had positive opinions about these courses. In addition, their attitudes towards 'School Experience' and 'Teaching Practice' courses have a very high average. This research shows that, these courses make significant contributions to the professional development of students. However, no significant difference was observed in terms of the gender factor based on the opinions of the participants with respect to the aforementioned courses.
\end{abstract}

Key Words: School Experience, Teaching Practice, French as a Foreign Language, Prospective French Teacher, Attitude

\section{Introduction}

The training of teachers, responsible for the education of the future generations, depends on a qualified education system. Therefore, for educational purposes, as stated in the Recommendation on the Status of Teachers prepared by UNECSO/ILO in 1966, "states should not only be 
satisfied with quantity but also try to increase quality". As stated in the same document, education is a continuous process and all elements of the education service must be coordinated so that all students receive quality education (OIKR, 2014).

According to Hammond (2010), who has a lot of work on education policy and practice, based on successful education systems and international comparisons, the policies to be followed for quality and equitable education as follows :

Meaningful learning goals: Students should be provided with knowledge and skills, including the skills needed for the 21 st century.

Mutually accountable systems: Students should be provided with adequate learning opportunities and curriculum, teaching and school capacity should be continuously evaluated and improved. Strategies that increase good practices and reduce bad practices, identify the causes of failure, and improve education should be used.

Equal and sufficient resources: All students should be provided with the resources necessary to reach the specified learning standards. In addition, arrangements should be made to prioritize student needs and to ensure that all children have access to qualified teachers.

Strong professional standards and supports for all educators: Educators should be provided with quality pre-service training, in-service training and guidance, and support and rewards should be given to those who work in difficult conditions. Career development systems should encourage teachers to take on roles as mentors, master teachers, program specialists and school leaders, thus supporting them to use their experience for the improvement of the education system.

School organization that enables students and teachers to learn: Schools should allow educators to develop a coherent curriculum focused on critical content and skills. In addition, realistic measurements and evaluations should be used to reflect the use of knowledge in the real world.

Another researcher, Stewart (2012), in his research on countries with qualified education systems such as Finland, Canada, China and Singapore, identified some common features about the education systems of these countries. These:

- vision and leadership,

- ambitious standards,

- commitment to meritocracy,

- high-quality teachers and principals,

- alignment and coherence,

- curriculum, instruction, and assessment system,

- accountability,

- $\quad$ student motivation, 
- global and future orientation.

As can be understood from the above features, a qualified education system must contain many elements and teachers are also at the center of these elements. According to Hammond (2006), teacher education is important, because teachers clearly affect student learning. The extent and quality of teacher education matter for teachers' effectiveness and add significant value to the general knowledge and skills that teachers with a strong subject matter background bring to the classroom.

Therefore, teachers have always been valued by every society since they play a major role in the process of students' knowledge accumulation, development of skills and vision and determination of their future career (Karataş, 2020). Teaching is becoming a profession whose importance is increasing day by day. In this respect, it can be said that the future of a country depends on the good training of teachers and their professional and personal qualifications to fulfill their duties in the best way (Eristi \& Odabasi, 2011).

While some professions can only be built on the theoretical knowledge others require the practice of theoretical knowledge (Kale, 2011). The teaching profession involves training processes in which both theoretical knowledge is gained, and necessary practices are performed for use in daily life. The way to train a good teacher is only possible with a good theoretical education alongside of practice activities to be performed accordingly. In countries such as Finland, Canada, China and Singapore with successful education systems, teachers play an important role both in improving the system and in their own development. In addition, they make some applications according to the needs of the students (OIKR, 2014). Teachers also prioritize their researcher identities during the practices and work on various subjects for the academic development of students. For example, in Singapore, it is important for teachers to conduct research on their professional fields according to the needs of students. Almost all teachers are involved in research and innovation projects examining their teaching and learning to better meet the needs of students (Hammond et al., 2017).

The knowledge and skills required for the teaching profession are grouped under three categories such as subject matter knowledge, general culture and professional teaching knowledge (Ekinci \& Basaran: 2015). 'subject matter knowledge'

The skills and knowledge required for the profession of teaching are collected in three groups such as subject matter knowledge, general knowledge and professional teaching knowledge. (Ekinci\& Başaran: 2015: 14). Subject matter knowledge refers to the knowledge with respect to the subjects to be instructed by the teacher and has already been studied. Professional teaching knowledge includes the type of knowledge about the manner to teach the knowledge that the teacher has gained regarding the profession. Yet another professional quality is General knowledge (Yilmaz \& Kab, 2013). The more 
teachers have cultural knowledge accumulation, the valuable their professional roles are considered. Therefore, what is expected from a teacher is not only having a professional knowledge but also having further knowledge about the world, society, and individuals. Within this context, the process of teaching practice, is a real/ concrete indicator of prospective teachers' competence in terms of subject matter knowledge, pedagogical formation, general knowledge and teaching skills (Yesilyurt ve Semerci, 2011, cited by Girmen et al., 2016).

Therefore, pre-service training is significant in terms of enabling the use of the knowledge acquired by the prospective teachers in addition to the vocational training received at the faculty. Accordingly, since the prospective teacher cannot be expected to think reflectively without experiencing the observations and practices in the real school environment, the contribution and influence of the administrator, the practice teacher and the school environment on the prospective teacher in the practice school are also significant.

Prospective teachers learn to teach by putting into practice the theoretical knowledge they have received in the faculty and their observations in practice schools. Accordingly, the prospective teachers cannot be expected to think reflective without experiencing observations and practices in the real school-setting, the contribution and impact of the administrator, the practice teacher and school's environment in the practice school are of utmost importance for the prospective teachers. (Hobson et al., 2009, cited by Alkan et al., 2013). In the pre-service trainings, prospective teachers have a chance to gain professional qualifications by taking a more active role in class environment and having an opportunity to develop their skills for practice. According to Bakircioglu (2016) the proficiencies that the qualified teachers are required to have are listed as follows (Karatas, 2020);

- Improving themselves in their field of education,

- Specializing in specific fields,

- $\quad$ Planning the time and setting,

- Utilizing sources of information,

- Inventing/ Producing new knowledge in the field,

- Program developing,

- Configuring learning processes,

- Using education environment,

- Conducting education activities,

field

- Knowing and applying their subject matter, field of teaching, the

of study as a teaching discipline and instructional technology,

- Counselling and guiding,

- Working with the team.

Eristi \& Odabasi (2011) suggest a more detailed list of the main and sub-competencies of teachers' professional competencies: 
- Personal and Professional Values- Professional Development:

- Valuing, understanding and respecting students,

- Believing that students can learn and succeed,

- Caring about national and universal values,

- Doing self-assessment,

- Ensuring personal development,

- Following and contributing to professional developments,

- Following professional laws, fulfilling duties and responsibilities.

- Getting to know the student:

- Recognizing developmental features,

- Considering interests and needs,

- Valuing the student,

- Guiding the student.

- Learning and teaching process:

- Lesson planning,

- Material preparation,

- Organizing learning environments,

- Organizing extracurricular activities,

- Diversifying teaching by observing individual differences,

- Time management,

- Behavior management.

- Monitoring and evaluation of learning:

techniques,

- Determining measurement and evaluation methods and techniques,

- Measuring student learning by using different measurement

- Reviewing the teaching-learning process.

- Curriculum and content information:

- The aims and principles of Turkish national education,

- $\quad$ Special field curriculum knowledge and application skills.

In order for a teacher to gain the abovementioned qualities, a wellorganized teacher training process is required aligned with the pre-service training.

\section{Teacher Training Process}

The studies aiming to enhance the quality of teachers in Turkey are based on many years of experience. "Teacher training applications have a history of 166 years. Within the Republic Period, efforts performed for the training of the teachers have been increased under the leadership of M.K. Atatürk. By his quote, "Teachers, the new generation will be your legacy.", Atatürk emphasized that teachers have the most substantial role in raising new generations." (Demir et al., 2015). 
Turkey has gained significant experience with regards to teacher training and in practice during the Republic Period. Within this period, teachers have been trained by institutions such as Teacher courses, Village Institutes, Primary Teacher Education Schools, Higher Teacher Education Schools, Education Institutes, Teachers Academy/Education Academy, Teachers Colleges/ Faculties of Education" (Saritas, 2007).

Nowadays, studies and discussions about incompatibilities between the theory and practice in teacher training have led to this situation reviewed within the teacher training process (Ekinci \& Basaran, 2015). Since it is considered that prospective teachers are sufficient in terms of subject matter knowledge but they lack in terms of knowledge and skills for the practice of the teaching profession, "certain endeavors and studies have been performed within the framework of the COHE (Council of Higher Education)/World Bank National Education Development Project, accomplished in 1994 with the aim of enhancing the quality of pre-service teacher training and the issue of training of the qualified teachers has been discussed accordingly (Ayvaci et al., 2019). As consequence of these studies, it has been concluded that the formation of teaching has not been provided enough to prospective teachers in Teachers Colleges/Faculty of Education. In another words, it has been revealed that the prospective teachers are sufficient in terms of subject matter knowledge, but they lack in terms of knowledge and skills for the practice of the teaching profession (Harmandar et al., 2000).

However, the school practices constitute the substantial and noteworthy part of the pre-service training. According to worldwiderecognized approaches of Theory - Practice and Practice - Theory in the training of teachers, it is considered that theoretical knowledge shall not make sense for prospective teachers, unless prospective teachers are encountered with knowledge and skills that they need in a real classroom-setting (Kose, 2014). The Theory-Practice Approach, is qualified as the fact that pre-service training provided to teachers is based on theory and that this theoretical knowledge is provided without an association to learning activities in the real classroom-setting. Based on the Practice - Theory approach, it is emphasized that more time should be allocated to studies involving in-class practices rather than theoretical courses in teacher training programs (Azar, 2003, cited by Demir et al., 2015). Accordingly, it is considered that as students experience the knowledge they learn in real classroom environment, they will be more interested, willing, and motivated towards profession of teaching therefore, positive attitude and willingness to learn towards the profession shall be enhanced.

The requirement of practice in gaining professional experience and maturity of prospective teachers preparing for the profession of teaching is not a new approach and that "assistance is required to be sought from the experienced ones in the process of practice" dates to early 1900s. With John 
Dewey acting as pioneer for the learner-oriented teacher training approach, practice aspect in the pre-profession training of the prospective teachers become prominent." (Kiraz, 2003). However, at the beginning, the preprofession training of the prospective teachers is performed only by going to schools and observing the classroom and school environment. Subsequently, it has been observed that such practice was not sufficient for the prospective teachers in terms of gaining professional experience.

In the mid 1980s, the aspect of observation was supported with in-class practices by discussing the teacher training approaches thoroughly, gaining a holistic dimension in teacher training and strengthening conceptual knowledge through observation and practice, concept-observation-practice approach became prominent. (Carnegie Forum, 1986, Holmes Group, 1986, cited by Kiraz, 2003).

Prospective teachers are expected to put their theoretical knowledge into practice within real classroom setting by teaching one of the important stages in teacher training. Teaching profession practices can be carried out in different variations in lot of countries around the world. For instance, in France, England, Germany and the USA, the plethora of practice period and the intensity of field and individual studies as well as knowledge on theoretical level stand out, whereas in Finland, providing opportunity for an intense communication and visits between the prospective teachers and the practice teacher comes to the fore (Aslanargun, Kilic \& Acar, 2012, cited by Karatas, 2020).

Similar with the practices around the world, prospective teachers who have reached a significant degree in terms of subject matter knowledge with undergraduate education in Turkey, are required to reinforce their knowledge with practical lessons. For that purpose, practical courses have been included in teacher training and COHE (Council of Higher Education) has introduced an obligation upon the Faculties of Education to exercise School Experience and Teaching Application courses.

\section{The Course of School Experience}

The teachers are primarily responsible for the formation of the society in a healthy manner and thus shape the future of the society. It has become mandatory for the teachers responsible for carrying out such an important task to be trained in accordance with the qualifications required by this profession. In Turkey, the training of the teachers used to be conducted by the Ministry of National Education until 1982 which was subsequently taken over by the universities completely (Kara \& Altuntas, 2013). As a result of the studies of the board examining the lecturer training programs of countries such as America and England, education faculties were restructured (Demir et al., 2015). Accordingly, COHE (The Council of Higher Education) established the Faculty-School Cooperation program in the process of restructuring 
education faculties in 1998 and it was ensured that the practice activities were executed according to the guide prepared with the same name (Silay \& Gok, 2004). Since this date, including the French Language Teaching undergraduate program, the School Experience course has taken its place in many undergraduate programs that have started to be implemented in education faculties in Turkey. "School Experience is defined as a course based on observations and interviews, presented to enable the prospective lecturer to get to know the school, students, program and teachers in general" (COHE, 1998). While the School Experience course was offered in two separate terms as School Experience I and School Experience II in the lecturer training programs of education faculties between 1998 and 2007, after 2007, the education faculty lecturer training undergraduate programs were renewed by $\mathrm{COHE}$ and the courses provided in two separate periods were reduced to a single course (Arseven \& Orhan, 2018).

The purpose of the School Experience course is as follows (Yesil \& Caliskan, 2006; COHE, 1998):

- To introduce the organizational structure, functioning and lecturing with a systematic approach to the prospective teachers,

- To provide prospective teachers with information about the school administration and the work and the resources available at the school,

- To enable prospective teachers to recognize other activities in the classroom and school through observation,

- To enable prospective teachers to recognize individual differences among students in terms of learning and development,

- To ensure that the prospective teachers acquire the necessary skills to work efficiently and harmoniously with other teachers at school.

Within the scope of this course, there are several responsibilities that prospective teachers must fulfil. These are as follows (COHE, 1998):

- preparing a term plan,

- observing a day of the lecturer in the practice school (how the experienced teachers start a lecture, how she/ he communicates with the students during the lecture and how she/ he completes the lesson, how she/ he draws the attention of the students fort he lecture, how she/ he uses the tone of voice, what teaching methods she/ he uses while teaching, how she/ he asks questions to the students, etc.),

- observing one day of one of the students in the practice school,

- learning the lecture management and classroom control,

- recognizing school equipment,

- getting to know the school principal and learning the school rules,

- assessing the studies of the students,

- questioning exercises,

- preparing and using worksheets,

- preparing tests, scoring and analysis, 
- $\quad$ they make observations and activities on subjects such as planning the lesson and sequencing the activities. Such activities provide prospective teachers with experience in learning classroom management, using teaching methods and getting to know students. Thus, prospective teachers become ready for the Teaching Practice course in the next step.

For the School Experience course to be carried out regularly and in accordance with its purpose, the following practices are anticipated to be conducted by the relevant persons (COHE, 1998):

- The practice coordinator the related department plans a number of activities for the practice and prospective teachers who will teach the School Experience course and determines the week in which each activity will be held,

- Announces the plan prepared to the practice instructors, practice teachers and prospective teachers assigned in this course,

- Prospective teachers prepare a report on the activities specified and completed in the plan. A copy of the report is given to the practice instructor,

- $\quad$ Practice instructors hold meetings with prospective teachers from time to time, discuss the observation results and give feedback,

- Practice instructors go to practice schools from time to time and help the course to be carried out in accordance with its purpose.

School Experience course is offered in the 7th semester of the French Language Teaching Program, including 4 hours of practice (observation at the practice school) and 1 hour of theoretical education (interview with the practice instructor). This period is "thought to be sufficient for prospective teachers to observe at schools, reflect on their observations and gain experience in teaching skills" (COHE, 1998).

Since it is not possible to start a job or graduate from a university without practicing in the field in certain professions such as engineering, medicine and nursing, it will also not be sufficient to graduate from a university based on limited observations in the profession of teaching that requires taking serious responsibilities. Therefore, prospective teachers who successfully complete the School Experience course take the Teaching Practice course in the next term (8th semester).

\section{Teaching Practice Course}

Teaching Practice course is defined as a course in which prospective teachers have the opportunity to practice the professional and theoretical knowledge they learned at the faculty in a real educational environment, realize their shortcomings and improve themselves, and gain experience in the professional field. This course is a preliminary study of senior students who are in the process of becoming a lecturer (Paker, 2008, cited by Avc1 \& İbret, 2016). At the same time, "school practice courses enable prospective teachers 
to realize whether they are suitable for the teaching profession, to gain professional experience and to socialize" (LaMaster, 2001, cited in Becit, 2009).

Sarıçoban (2008) stated that the Teaching Practice is a course that the candidates develop their professional competencies; they learn to use the textbooks and other tools belonging to their field; they make assessment and evaluation, and improve themselves by sharing their work with the advisory teacher, university practice course lecturer and other trainee friends (Avci \& Ibret, 2016).

This course is carried out in the form of 6 hours of practice per week (to teach by going to the practice school) and 2 hours of theoretical education at the faculty (interview with the practice instructor) in the French Teaching Program. While the prospective lecturer observes the teaching process in the School Experience course, he/she is personally involved in the Teaching Practice course.

The prospective lecturer can attend the lectures for up to 6 hours with the guidance of the practice lecturer and makes the necessary preparations when he will lecture during his time at the practice school. For instance, she/ he prepares worksheets related to the course to be taught by adhering to the curriculum of the National Education, lectures using the technological tools (Web 2.0 tools, smart board, overhead projector, mobile phone, etc.) and makes the students do activities, meets with the practice teachers and gets feedback about the lecture taught and makes self-evaluation at the end of the lecture.

Upon completion of this course, prospective teachers are expected to have acquired the following qualifications (COHE, 1998):

To be able to develop the competencies of the teaching profession by teaching in different classes in the practice school,

- $\quad$ To be able to understand the syllabus of his own field, to evaluate the textbooks, to be able to assess and evaluate,

- $\quad$ To be able to develop himself/herself accordingly by sharing the experiences she/ he has gained during teaching practice with their friends and practice instructors 1998):

The functioning of the Teaching Practice course is as follows (COHE,

1. Prospective teachers are placed in the schools where they will do internships via the university's web address by the practice instructor. In other words, practice teachers are determined according to the curriculum of the prospective teachers.

2. The faculty practice coordinator informs the Directorate of National Education about the number and names of the prospective teachers as well as the names of the practice instructors and the names of the schools determined 
by the practice coordinators of the related department with respect to the place of the practice.

3. The Directorate of National Education send the approved lists to the relevant practice schools and faculty practice coordinators.

4. The faculty practice coordinator sends the list (number and names of prospective teachers, names of the practice instructors) approved by the Directorate of National Education to the practice schools.

5. The practice lecturer plans the activities to be conducted during the practice process together with the prospective teachers and the practice instructors based on the weeks.

6. After each lecture of the prospective lecturer, the practice lecturer records her/ his observations on the lecture observation form and provides feedback to the prospective lecturer about her/ his weak points and advises for self-development. "Some researchers state that the process between the prospective lecturer and the practice lecturer is beneficial not only for the candidate but also for the lecturer in terms of improving teaching behaviours (Crowther \& Cannon, 1998; Healy, Ehrich, Hansford and Stewart, 2001, cited in Basturk, 2010).

7. The practice instructor and the practice lecturer participate in the lectures to listen to each prospective lecturer while they are teaching and evaluate them using the assessment chart (4-day assessment +1 general assessment). As a result of this evaluation, it is determined whether the prospective lecturer is successful in the Teaching Practice course. The grades given to the students in the assessment are entered into the system through the relevant web page of the Ministry of National Education.

8. During the semester, the practice instructor interviews the prospective teachers at the faculty and discusses the positive and negative situations observed by the prospective teachers in the classes. Dallmer (2004) drew attention to the fact that the success of the practices in lecturer training depends on the real cooperation between the parties as anticipated. According to him, shared experiences and criticisms among practice teachers, instructors and students will support change (Gundogdu, 2010).

9. At the end of the practice, the prospective lecturer delivers all the work he has prepared for the lectures to the practice instructor as a file.

In this study, the attitudes of the prospective teachers, studying in the field French language at the Faculty of Education in Anadolu University, towards School Experience and Teaching Practice courses offered in education faculties of universities in Turkey have been determined and it has been researched whether the attitudes towards these courses vary according to the gender factor. The research is important since the number of studies on prospective teachers in the field of French language is negligible in the literature although many studies are available related to these courses. It is also significant in terms of revealing whether these courses contribute to the 
professional development of prospective teachers. Accordingly, responses to the following research questions were sought:

1. What is the level of prospective teachers' attitudes towards School Experience and Teaching Practice courses?

2. Do prospective teachers' attitudes towards School Experience and Teaching Practice courses differentiate in terms of gender?

3. What are the opinions of prospective teachers about School Experience and Teaching Practice courses?

\section{Method}

\section{Research Model}

The research has been conducted by means of a descriptive survey model. "Survey models are research approaches that aim to describe a past or present situation as it exists. The event, individual or object that is the subject of the research is defined as it exists under its own conditions. No attempt is made to change or influence them in any way" (Karasar, 1995). In addition, qualitative and quantitative research designs were used in the research.

\section{Study Group}

In this study, convenience sampling method was used. By means of this sampling technique, it is aimed to conduct the research with the participants who are accessible and join the study voluntarily (Creswell, 2005). The research was carried out with a total of 18 volunteer students (10 females, 8 males) studying at Anadolu University Education Faculty French Language Teaching Program. Descriptive information about the participants is given in Table 1.

Table 1. Distribution of prospective teachers by gender

\begin{tabular}{lll}
\hline Gender & $f$ & $\%$ \\
\hline Female & 10 & 55.6 \\
Male & 8 & 44.4 \\
\hline Total & 18 & 100.0 \\
\hline
\end{tabular}

As shown in Table 1, $55.6 \%$ of the participants were female ( $\mathrm{f}=10$ ), while $44.4 \%$ of the participants were male $(\mathrm{m}=8)$. Although the ages of the prospective teachers vary between 22 and 43, the average is 26 .

\section{Data Collection Tools}

The attitudes of the participants towards the School Experience and Teaching Practice course were measured with a 5-point Likert-type rating scale consisting of 30 items prepared in Turkish, used by Köse (2014) in the relevant study. The scale is rated as (1) Strongly Disagree, (2) Disagree, (3) Indecisive (4) Agree, (5) Totally Agree. As Kose (2014) has stated, previous studies on this subject (Harmandar et al., 2000; Azar, 2003; Oguz, 2004; 
Ozmen, 2008) have been used in the formation of the propositions in the survey. For the reliability of these measurement tools, they were applied to 20 education faculty students and the cronbach alpha coefficients were calculated as 0.75 and 0.68 , respectively. For validity, the opinions of 2 experts were consulted and it was concluded that the questionnaire could be used in its current form.

To be able to find an answer to the 3rd question of the research, qualitative data has been collected by means of 5 open-ended question drawn up by the researcher for the purpose of enabling the student to express their opinions on the relevant courses in a more comfortable manner:

1. Do you think that School Experience (SE) and Teaching Practice (TP) courses are beneficial for you? Why?

2. What are the positive or negative effects of SE and TP courses on your opinions with respect to the teaching profession?

3. Have you had any difficulties in SE and TP courses? What are those?

4. Do you think SE and TP courses are sufficient in terms of time?

5. Do you think that such courses are required to be implemented within the teacher training programs? Why?

Opinions of 2 academicians have been sought with regards to the convenience of the questions. Questions were handed to the students at the end of the term and they were asked to reply them. Data acquired has been analyzed through the document analysis method. "The document analysis refers to a systematic method applied to examine and evaluate the entire documents, including printed and electronic materials (Kiral, 2020). The importance of the documents and how they are used as the data resources are closely associated with the study problem. For instance, in an educational study, documents such as textbooks, lecture notes, student homeworks and examinations, memoirs, diaries, private correspondences can be the subject of document analysis (Bailey, 1982).

\section{Analysis of Data}

Statistical data analysis program was used in the analysis of the quantitative data of the research. Mann-Whitney $U$, one of the non-parametric tests and the averages of responses given to the items, were used in the analysis of the research questions. The first one was used to respond the 1 st research question and the other was used for the 2 nd research question. The qualitative data acquired in this study has been reviewed through the document analysis method.

\section{Findings and Interpretation}

In order to find a response to the first research question (What is the level of attitudes of prospective teachers towards School Experience and Teaching Practice courses?), the averages of the responses given to the items 
were used to determine the attitudes of prospective teachers towards School Experience and Teaching Practice courses. The said information is presented in Table 2.

Table 2. Attitudes of Prospective Teachers Regarding School Experience-Teaching Practice Courses

\begin{tabular}{lc}
\hline \multicolumn{1}{c}{ Items } & $\overline{\boldsymbol{x}}$ \\
\hline 1. Through the School Experience/Teaching Practice, I realized that the teaching & 4.61 \\
profession requires willingness that cannot be performed against will or just by & \\
considering the financial aspect. &
\end{tabular}

2. The School Experience/Teaching Practice courses helped me get to know the 4.39 teaching profession.

3. I believe that the School Experience/Teaching Practice courses are beneficial 4.56 for the prospective lecturer.

4. The School Experience/Teaching Practice gave me the opportunity to observe and practice at different grade levels.

5. Through the School Experience/Teaching Practice, I started to consider myself as a lecturer and my self-confidence increased.

6. Through the School Experience/Teaching Practice, I learned the duties of the employees (Manager, Assistant Manager, service personnel, etc.) at the school.

7. I believe that I gained the knowledge and skills necessary for teaching through the School Experience/Teaching Practice.

8. I would attend School Experience/Teaching Practice classes even if they had zero (0) credit

9. School Experience/Teaching Practices should be done not only in the city centers but also in village schools.

10. I think that the time allocated to School Experience/Teaching Practice courses is insufficient.

11. I liked the teaching profession more with the School Experience/Teaching Practice courses.

12. Through the School Experience/Teaching Practice, I learned how to establish a healthy communication between the lecturer and the student.

13. Through the School Experience/Teaching Practice, I learned how to evaluate students' performance with grades.

14. School Experience/Teaching Practice made me understand whether the teaching profession is suitable for me.

15. I learned how to leverage many resources with School Experience/Teaching Practices.

16. During the School Experience/Teaching Practice, my lecturer at the practice school helps me with all kinds of problems related to these lessons.

4.50

17. During the School Experience/Teaching Practice, my practice instructor helps me with all kinds of problems related to these courses.

18. I believe that the School Experience course reports are assessed objectively by my advisor. 
19. I believe that there is a healthy communication between faculties and practice

3.89 schools in School Experience/Teaching Practice courses.

20. I believe that it is necessary for prospective teachers to gather at school after the School Experience/Teaching Practice classes.

21. The School Experience/Teaching Practice gave me the opportunity to compare the characteristics between my own personality and the personality of a good lecturer.

22. Through the School Experience/Teaching Practices, I learned how a teacher can dominate the classroom.

23. Through School Experience/Teaching Practice; I learned how to prepare annual, unit and daily plan.

24. Through School Experience/Teaching Practice, I learned how a teacher should prepare exam questions.

25. I got to know the functioning of the National Education system with School Experience/Teaching Practice.

26. Through the School Experience/Teaching Practice, I learned to teach based on the level of the students.

27. Through School Experience/Teaching Practice, I learned that rhetoric and tone of voice are effective.

28. I believe that School Experience/Teaching Practice courses should be in education faculties in terms of teaching experience.

29. In the School Experience/Teaching Practice courses, the intensity of my lectures at the faculty affects me negatively in terms of the efficiency of the practice.

30. As a prospective lecturer (self-criticism), I care enough about School Experience and Teaching Practice courses.

4.50

4.44

Total

As shown in Table 2, it was determined that the prospective teachers responded to the propositions in which their attitudes towards the courses were determined, with $(\overline{\mathrm{x}})=4.03$ as "I agree". This situation can be considered as an indication that the attitudes of the participants towards the courses are generally good and positive.

According to the survey, the items with the highest average are numbered 1, 18 and $28(\bar{x}=4.61)$. Since the statement in the first item, which contains one of the most important propositions of the survey, "Through the School Experience/Teaching Practice, I realized that the teaching profession requires willingness that cannot be performed against will or just by considering the financial aspect." was responded positively to a large extent, it can be argued that this may be due to the fact that the prospective teachers understood the moral value of their profession rather than the material dimension. Through the 18th item with the statement of "I believe that the School Experience course reports are assessed objectively by my advisor." it can be concluded that the prospective teachers have a sense of confidence in 
this regard. The majority of positive responses to the 28 items containing the statement "I believe that School Experience/Teaching Practice courses should be in education faculties in terms of teaching experience" can be considered as a valuable finding in terms of emphasizing how important the prospective teachers consider the courses in question in their curriculum.

Apart from the items mentioned above, the items with a high average are the items numbered 2, 3, 4, 14, 18, 22, 26, 27, 28 and 30. When these items are examined, it is observed that the School Experience and Teaching Practice courses guide students in getting to know the teaching profession, providing the opportunity to practice their profession at different grade levels, and understanding whether this profession is suitable for them. At the same time, it can be argued that the prospective teachers' learn to have a command on the classroom management and to teach based on the students' level and they realised that the lecturer's rhetoric and tone of voice are important.

In addition, based on the responses obtained, it can be said that the advisor instructors responsible for this course helped the prospective teachers during the course and acted objectively while evaluating their reports.

When the items other than the items with the highest average are examined, no averages below the 2.00 average are found. This shows that, in general, students have developed a positive attitude towards School Experience and Teaching Practice courses and are satisfied with the functioning of the courses. At the same time, it has been stated that these two courses contributed a lot to the students professionally and their selfconfidence increased through these courses and they began to consider themselves as teachers. It has been also observed that they started liking the teaching profession more, they have learned to establish a healthy communication with the students, and to prepare annual-unit and daily plans.

So much so that the candidate students think that these two courses should be given not only in schools in the city centres but also in village schools. This shows that prospective teachers attach sufficient importance to the courses in question. Briefly, it has been determined based on the averages of the responses that both courses contributed enough to the students in terms of professional gains.

Examining the results in Table 2, it is seen that no score below the average of 2.00 was found. The 10 th item has the lowest average $(\bar{x}=2.33)$. In this item it was stated that "I think that the time allocated to School Experience/Teaching Practice courses is insufficient" This situation can be considered as an evidence that the said courses are sufficiently included in the curriculum. Another item with the lowest average is the item numbered $29(\overline{\mathrm{x}}=$ 2.89). Through the item including the statement of "In the School Experience/Teaching Practice courses, the intensity of my lectures at the faculty affects me negatively in terms of the efficiency of the practice", it can be concluded that prospective teachers' courses in the faculty are not intense 
enough to affect the efficiency of their School Experience and Teaching Practice courses.

The Mann-Whitney $\mathrm{U}$ Test was used to answer the second question (Do prospective teachers' attitudes towards School Experience and Teaching Practice courses differentiate in terms of gender?) of the research. In case the independent variable has two sub-factors, independent samples t-Test is used among the parametric tests. However, the sample size should be at least 30 (Chakravarti, Laha \& Roy, 1967). When the number in question is considered in the context of the research question, it does not satisfy this condition $(n=18)$. The results of the analysis regarding whether the attitudes of prospective teachers towards School Experience and Teaching Practice courses change significantly according to gender are given in Table 3.

Table 3. Examining the attitudes of the participants towards the courses by gender

\begin{tabular}{cccccc}
\hline Gender & $\mathrm{n}$ & Rank Average & $\begin{array}{c}\text { Rank Averages } \\
\text { Total }\end{array}$ & $\mathrm{U}$ & $\mathrm{p}$ \\
\hline Female & 10 & 11.05 & 110.50 & 24.50 & .168 \\
Male & 8 & 7.56 & 60.50 & & \\
Total & 18 & & & & \\
\hline
\end{tabular}

As can be observed in Table 3, the average scores of the participants do not differ significantly by gender $(U=24.50, \mathrm{p}>.05)$. Therefore, it has been determined that there is no difference in the attitudes of male and female students participating in the research towards School Experience and Teaching Practice courses, and they have similar thoughts.

What are the opinions of prospective teachers about School Experience (SE) and Teaching Practice (TP) courses? In order to find an answer for the above-cited 3rd question of the study, the students were asked to answer 5 open-ended questions drawn up by the researcher.

Accordingly;

1. Do you think that SE and TP courses are beneficial for you? Why? It is revealed by the answer the above-cited first question that almost the entire prospective teachers think that the School Experience and Teaching Practice courses are beneficial. Because, they have stated that they were able to gain professional experience by these courses, they had the opportunity to put into practice they have learned in the courses at the faculty, their communication with the students was increased which made them appreciated, their selfconfidence was improved, and further recognized that the teaching is an highly important and sacred profession and they enjoyed while delivering the lesson: 
\# S1- "We had the opportunity to perform a preliminary preparation towards the teaching profession. Those are the courses enabled us to get closely acquainted with the teaching profession."

\# S2- "They were definitely very beneficial. Because we were able to have the opportunity to experience the entire possible issues we may encounter at school and learned how to tackle them.

\# S5- "I do believe that they are highly beneficial. Because, we had the opportunity to experience the teaching profession in person and experiencing the positive and negative aspects required to be encountered by experiencing the classroom-setting was a great accomplishment for us."

2. What are the positive or negative effects of SE and TP courses on your opinions with respect to the teaching profession? As it is revealed by the answers given to the above-cited questions, the majority of the prospective teachers stated that they enjoyed teaching students, that they learned that each student is with the unique character and accordingly their approach towards each student should be different, and that their positive opinions and perception on the teaching profession increased:

\# S4- "The internship experience enabled me to realize what I did right and wrong when I was teaching in the previous years."

\# S6- "Thanks to these courses, we had the opportunity to experience the joy of teaching to the students."

\# S7- "I have no negative opinions on these courses. I was able to observe the relationship between the students and teacher not as a student but a teacher." more."

\# S8- "I was able to see the reason why I preferred to be a teacher once

3. Have you had any difficulties in SE and TP courses? What are those? By the answers given to the above-cited question, certain prospective teachers have stated that they were not satisfied with the way the practice teacher evaluated them. Moreover, they mentioned that certain students were absent from the classes and this situation affected them adversely. The reluctance of the students to attend the course was expressed as an adverse situation:

\# S7- "I understood that our practice teacher was not aware of the duration of the course and subject selections of ours by his/her way of evaluating us."

\# S9- "Certain situations have been expressed such as absence of students and inability of the ones attending but not participating in the course."

\# S11- "I was not able to make certain students to be involved and participate to the course. This was highly demoralizing for me."

4. Do you think SE and TP courses are sufficient in terms of time? By the answers given to the above-cited question, almost the entire students have stated that the duration of the internship courses was satisfactory for them due 
to intensity of their courses at the faculty. Only 1 student believed that the duration is required to be extended:

\# S13- "Course durations were quite sufficient. The duration was sufficient as senior students would have other courses to be completed as well."

\# S14- "I believe it is sufficient. Because we could have other obligations and responsibilities (courses, exams, etc.) as a student."

\# S17- "Yes, both were sufficient in terms of duration."

\# S8- "I think that the duration is required to be increased even more in order to experience the feeling of teaching more in our senior year before starting the profession."

5. Do you think that such courses are required to be implemented within the teacher training programs? Why? By the answers given to the above-cited question, almost the entire prospective teachers have stated that they consider these two courses absolutely necessary and substantial, because the students have the opportunity to get closely acquainted to the teaching profession and gain experience. Furthermore, they stated that every prospective teacher is required to have internship experience and that these courses prepare them for the profession:

\# S12- "I consider it absolutely necessary, because these courses are of utmost importance in order to be prepared for the profession."

\# S18- "They are definitely required to be available. We had the opportunity to observe the student-teacher relationship and the course environment."

\# S15-"We observed one-on-one how to overcome minor setbacks in the courses and how we are required to communicate with students."

\# S16-“They are definitely required. Thanks to these courses, we have the opportunity to personally observe our deficiencies in pronunciation and effective speaking and find the opportunity to overcome these deficiencies before starting the profession."

As the answer to this question, only one student has pointed out that the said courses are not really required:

\# S13-"No, I don't think they are required. Because I think that if these courses and other courses we had related to professional knowledge were sufficient, we would not have examinations and interviews to practice our profession."

Table 4. The opinions of the students on the School Experience and

Teaching Practice course and the frequency and percentage distribution thereof

\begin{tabular}{|l|l|l|l|}
\hline Questions & Sample answers & $\begin{array}{c}\text { Mentioning } \\
\text { frequency/Total }\end{array}$ & \\
\hline
\end{tabular}




\begin{tabular}{|c|c|c|c|}
\hline & & $\begin{array}{c}\text { number of } \\
\text { participants }\end{array}$ & $\begin{array}{c}\text { Percent } \\
(\%)\end{array}$ \\
\hline $\begin{array}{l}\text { Question 1. Do you think } \\
\text { that SE and Teaching } \\
\text { Practice TP courses are } \\
\text { beneficial for you? Why? }\end{array}$ & $\begin{array}{l}\text {-Yes, we are gaining } \\
\text { professional experience. } \\
\text {-It led to the point that } \\
\text { certain colleagues of us } \\
\text { have recognized whether } \\
\text { they are suitable and fit for } \\
\text { this profession. }\end{array}$ & $17 / 18$ & 94.44 \\
\hline $\begin{array}{l}\text { Question 2. What are the } \\
\text { positive or negative } \\
\text { effects of SE and TP } \\
\text { courses on your opinions } \\
\text { with respect to the } \\
\text { teaching profession? }\end{array}$ & $\begin{array}{l}\text {-These courses had a } \\
\text { positive effect on me. It was } \\
\text { enjoying lecturing the } \\
\text { students and organizing } \\
\text { events with them. } \\
\text {-I was able to observe the } \\
\text { relationship between the } \\
\text { students and teacher not as } \\
\text { a student but a teacher. }\end{array}$ & $15 / 18$ & 83.33 \\
\hline $\begin{array}{l}\text { Question 3. Have you } \\
\text { had any difficulties in SE } \\
\text { and TP courses? What are } \\
\text { those? }\end{array}$ & $\begin{array}{l}\text {-I was not able to make } \\
\text { certain students to be } \\
\text { involved and participate to } \\
\text { the course. } \\
\text {-My practice teacher was } \\
\text { uninterested. }\end{array}$ & $3 / 18$ & 16.66 \\
\hline $\begin{array}{l}\text { Question 4. Do you think } \\
\text { SE and TP courses are } \\
\text { sufficient in terms of } \\
\text { time? }\end{array}$ & $\begin{array}{l}\text { - Yes, I believe both courses } \\
\text { are sufficient in terms of } \\
\text { duration. } \\
\text {-I think that the duration is } \\
\text { required to be increased } \\
\text { even more in order to } \\
\text { experience the feeling of } \\
\text { teaching more in our senior } \\
\text { year before starting the } \\
\text { profession. }\end{array}$ & $17 / 18$ & 94.44 \\
\hline $\begin{array}{l}\text { Question 5. Do you think } \\
\text { that such courses are } \\
\text { required to be } \\
\text { implemented within the } \\
\text { teacher training } \\
\text { programs? Why? }\end{array}$ & $\begin{array}{l}\text { - Yes, they are definitely } \\
\text { required. } \\
\text {-I believe every prospective } \\
\text { teacher is required to have } \\
\text { internship experience. }\end{array}$ & $17 / 18$ & 94.44 \\
\hline
\end{tabular}

As can be understood from Table 4, students mostly have positive opinions about these courses. They think that these courses should be in education faculties. Only a few of the students participating in the study reported negative opinions. 


\section{Conclusion and Recommendations}

In this study, it was tried to determine the attitudes of the prospective French teachers towards School Experience and Teaching Practice courses since attitudes have an active role in the emergence and development of actions. In the same way, actions can be effective in changing the attitudes that affect them in the development process (Inceoglu, 2004, cited by Kara \& Altuntas, 2013).

Considering the average of the responses given by the prospective teachers to the scale items $(\overline{\mathbf{x}}=4.03)$, they mostly have a common opinion in terms of developing a positive attitude towards the School Experience and Teaching Practice courses and that these two courses contribute to their professional development. The answers given by the pre-service teachers to open-ended questions support this statement. Many studies supporting this outcome (Baran et al., 2015; Ozdas \& Cakmak, 2018; Aslan \& Saglam, 2018; Tepeli \& Caner, 2014; Toksun, 2020; Altinok \& Eskimen, 2011) are available. For instance, through these lessons, prospective teachers stated that they learned to prepare daily weekly and monthly lecture plans and lecture materials, which will provide them with great convenience after they start their profession. This study reveals similarities with the outcome of certain studies (Oner \& Aydin, 2016; Oguz \& Avci, 2014; Saritas, 2007; Ozdemir \& Canakci, 2000). In these studies, prospective teachers stated that they believe these courses as beneficial in terms of their professional development and that these courses provided some benefits for them.

At the same time, it can be stated that they are able to establish a healthy communication with the students in the courses they teach, that they teach based on their level, that they had the opportunity to work with students at different grade levels and learned to evaluate the performance of students, that they gained experience in classroom management, observed whether they were suitable individuals for the teaching profession, their self-confidence increased and they began to consider themselves as teachers. However, another outcome of the study conducted by Toksun (2020) is in contradiction with this study. It was stated in the study conducted that regard prospective teachers as trainees and therefore they do not treat them as they treat their teachers. Likewise, in the study conducted by Boz \& Boz (2006), they stated that the prospective teachers do not consider themselves as the class teachers and therefore, they experienced certain issued accordingly.

In addition, from the responses obtained, it is revealed that prospective teachers value the teaching profession more morally than financially.

During the implementation process of the courses, it was determined that they had positive thoughts about both the teachers in the practice school and the practice instructors in the faculty. This outcome coincides with the studies conducted by Ozcelik (2012), Bektas \& Ayvaz (2012), Celikkaya 
(2011) and Sag (2008). It is understood through the responses obtained that the practice teachers and instructors helped the students by allocating time during the semester and evaluated their work impartially. This reveals that practice teachers and instructors fulfil their duties and responsibilities adequately. As a result, since such courses are not conducted individually by prospective teachers, when they have any problems or need academic support, they can overcome it with the help of the practice teachers and instructors. Whereas a situation contradicting with the outcome herein was revealed in the study conducted by Toksun (2020). Accordingly, while certain teachers have provided feedback to the prospective teacher candidates, some just have not. Again, a similar outcome is revealed in the studies conducted by Kocaturk (2006), Topkaya, Tokcan \& Kaya (2012), Ozmen (2008) and Saratli (2007). Accordingly, prospective teachers have stated that they were not sufficiently guided by the practice instructors and practice teachers, that they could not receive sufficient guidance and feedback on their reports, and that the counseling services offered were useful but not sufficient.

At the same time, it can be argued that these courses contribute to prospective lectures in terms of considering the school as an institution, being aware of the responsibilities of school staff, and getting to know the national education system and its functioning.

Examining the answers given by the prospective teachers (items 10 and 29) with the lowest average, it is observed that they think that the time allocated to SE and TP courses is sufficient and that the intensity of these courses does not adversely affect their courses in the faculty. Whereas one of the outcomes of the study conducted by Tepeli \& Caner (2014) is that the prospective teachers consider the practice duration insufficient. This outcome contradicts with the results in this study.

As a result, according to the findings obtained from the research data, it was observed that the SE and TP courses had positive effects on the teacher candidates. Similarly, it can be said that the majority of the students have positive thoughts about these two courses. This paper shows that, these courses make significant contributions to the professional development of students. In line with these results, the following suggestions can be made :

1. The effects of SE and TP courses on prospective teachers can be examined more comprehensively.

2. Prospective teachers' attitudes towards SE and TP courses can also be examined in terms of different variables (age, foreign language, practice teacher, practice instructor, practice school, school administrators, etc.).

3. The number of schools where French prospective teachers will practice can be increased. This can be achieved by expanding French teaching in primary education institutions and assigning French teachers to these institutions. In parallel, students who graduate from French Teaching Programs will have the opportunity to practice their profession. In this manner, 
students who prefer this department will be able to spend their student years in a more motivated way, as they will not have to worry about finding a job after graduation.

4. Before the practice, it would be appropriate for the prospective teachers to be introduced to other teachers so that they do not feel alienated at the practice schools and that they are considered as colleagues. An orientation can be organized by the school administration and the practice lecturer to achieve this purpose. 


\section{References:}

Alkan, V., Simsek, S., \& Erdem, A.R. (2013). The Directors' and Teachers' Suggestions for The Teaching Experience Lesson. E-Journal of New World Sciences Academy, 8(2), 245-260.

Aslan, M., \& Saglam, M. (2018). Evaluation of Teaching Practice Course According to Opinions of Student Teachers. Hacettepe Universitesi Egitim Fakultesi Dergisi, 33(1), 144-162.

Arseven, I., \& Orhan, A.T. (2018). An Evaluation of School Course Teaching Experience Program According to Teacher Candidates and Alternative Program Proposal. Mehmet Akif Ersoy Universitesi Egitim Fakultesi Dergisi, 47- 461-490.

Ayvac1, H.S., Ozbek, D., \& Bulbul, S. (2019). Evaluation of Teaching Practice Lesson Expectations and Its Process. Bolu Abant Izzet Baysal Universitesi Egitim Fakultesi Dergisi, 19(1), 57-66.

Avc1, E.K., \& Ibret, B.U. (2016). Evaluation of Teacher Candidates' Views Regarding to Teaching Practice-II. Kastamonu Egitim Dergisi, 4(5), 25192536.

Bailey, K. D. (1982). Methods of Social Research. The Free Press.

Baran, M., Yasar, S., \& Maskan, A. (2015). Evaluation of Prospective Physics Teachers' Views Towards The Teaching Practice Course. Dicle Universitesi Ziya Gokalp Egitim Fakultesi Dergisi, 26, 230-248.

Basturk, S. (2010). According to Mentor Teachers The Group of School Experience Courses and Teacher Candidates. Turk Egitim Bilimleri Dergisi, 8(4), 869-894.

Becit, G., Kurt, A. A., \& Kabakci, I. (2009). Determination of the Learning Priorities of Students in Department of CEIT Based on Their Career Preferences Using AHP. Anadolu Universitesi Sosyal Bilimler Dergisi, 9(1), 169-184.

Bektas, M., \& Ayvaz, A. (2012). Ogretmen Adaylarinin Ogretmenlik Uygulamasi Dersinden Beklentileri. Mersin Universitesi Egitim Fakultesi Dergisi, 8(3), 209-232.

Chakravarti, I., Laha, R., \& Roy, J. (1967). Handbook of Methods of Applied Statistics, John Wiley and Sons 1, 392-394.

Creswell, J. W. (2005). Educational Research: Planning, Conducting, and Evaluating Quantitative and Qualitative Research. Pearson Education, Inc.

Celikkaya, T. (2011). Expectations of Preservice Social Studies Teachers from the Lesson of Teaching Practice and Fulfilment Levels of These Expectations. Uluslararast Sosyal Bilimler Egitimi Dergisi, 1(2), 1-18.

Demir, M.K., Sahin, C., \& Arcagok, S. (2015). Assesing Elementary Student Teachers' Attitudes Towards School Experiences. Dicle Universitesi Ziya Gokalp Egitim Fakultesi Dergisi, 25, 136-156. 
Ekinci, N., \& Basaran, S.T. (2015). The Effect of School Experience Course on Teaching Perceptions of Pre-Service Teachers. MSKU Egitim Fakultesi Dergisi, 2(1), 13-24.

Eristi, B. \& Odabasi, H. F. (2011). Ogretmenlikte Mesleki Gelisim. Anadolu Universitesi Yayinlari.

Altınok, S., \& Eskimen A. D. (2011). Turk Dili Edebiyati Ogretmen Adaylarinin Okul Deneyimi Dersine Yonelik Gorusleri. 2nd International Conference on New Trends in Education and their Implications. Siyasal Kitabevi.

Girmen, P., K1lic, Z., \& Kaya, M.F. (2016). The Investigation of Instructional Practices of The Primary School Teacher Candidates Within Teaching Practice Course. Egitim ve Insani Bilimler Dergisi, 7 (13), 89-108.

Gundogdu, K., Coskun, Z.S., Albez, C., \& Bay, E. (2010). The Opinions and Expectation of Teacher Trainee About Teaching Practice. Bayburt Universitesi Egitim Fakultesi Dergisi, 5(1-2), 55-67.

Hammond, L.D., Burns, D., Campbell, C., Goodwin, A.L., Hammerness, K., Low, E.L., McIntyre, A., Sato, M., \& Zeichner, K. (2017). Empowered Educators: How High-Performing Systems Shape Teaching Quality Around the World. John Wiley \& Sons.

Hammond, L. D. (2010). The flat world and education: How America's Commitment to Equity Will Determine our Future. Teachers College Press.

Hammond, L.D. (2006). Powerful Teacher Education: Lessons from Exemplary Programs. Jossey-Bass.

Harmandar, M., Bayrakceken, S., Kincal, R.Y., Buyukkasap, E., \& Kizilkaya, S. (2000). Kâzim Karabekir Egitim Fakultesinde Okul Deneyimi Uygulamasi ve Sonuclarinin Degerlendirilmesi. Milli Eğitim Dergisi, 148, 3-6.

Kale, M. (2011). The Problems of Prospective Teachers During Teaching Practice Course. Turk Egitim Bilimleri Dergisi, 9 (2), 255-280.

Kara, O.T., \& Altuntas, I. (2013). Attitudes of Pre-Service Teachers of Turkish Language Teaching Towards to School Experience Course. Mersin Universitesi Egitim Fakultesi Dergisi, 9(3), 115-132.

Karatas, K. (2020). A Theoretical View of the Teaching Profession. Elektronik Egitim Bilimleri Dergisi, 9 (17), 39-56.

Kiral, B. (2020). Document Analysis as a Qualitative Data Analysis Method. Siirt Universitesi SBE Dergisi, 15, 170-189.

Kiraz, E. (2003). Supervising Teacher Competency Scale (STCS). Turk Egitim Bilimleri Dergisi, 1(4), 0-0.

Kocaturk, F. (2006). The Opinions of University Instructors, Mentor Teachers and Prospective Teachers Concerning School Experience II Course. [Unpublished Master's Thesis]. Hacettepe Üniversitesi.

Kose, E.O. (2014). Students' and Teachers-University Teachers' Attitudes of School Experience and Teaching Practice (Sample of Erzurum). Dicle Universitesi Ziya Gokalp Egitim Fakultesi Dergisi, 22, 1-17. 
Oguz, S., \& Avci, E. (2014). Views of Social Studies Teacher Candidates' About School Experience Course. Cumhuriyet International Journal of Education-CIJE, 3(3), 40-53.

Oner, G., \& Aydin, E. (2016). Oğretmen Adaylarinin Okul Deneyimi ve Ogretmenlik Uygulamasi Derslerinden ve $\mathrm{Bu}$ Derslerin Paydaslarindan Beklentileri. ERPA International Congresses on Education-Book of Proceedings, Sarajevo.

Ozdas, F., \& Cakmak, M. (2018). Metaphor Perceptions Related to The Teaching Practice of Teacher Candidates. Uluslararası Turkçe Edebiyat Kultur Egitim Dergisi, 7(4), 2747-2766.

Ozdemir, A.S., \& Canakci, O. (2000). The effect of School Exprience-I Course on Turkish Pre-Service Elementary Mathematics Teachers' Understandings About The Concepts of Teaching- Learning and Student and Teacher Roles. Ilkogretim- Online, 4(1), 73-80.

Ozmen, H. (2008). Student Teachers' Views on School Experience I and II Courses. Ondokuz Mayıs Universitesi Egitim Fakultesi Dergisi, 25, 25-37.

Sag, R. (2008). Evaluation of Prospective Physics Teachers' Views Towards The Teaching Practice Course. Eurasian Journal of Educational Research, 32, 117-132.

Saratli, E. (2007). The qualifaction of mentoring serves that presented to the secondary school science student teachers during school experience-I training (Siirt Province Example). [Unpublished Master's Thesis]. Gazi Universitesi. Saritas, M. (2007). Evaluation of The Opinions About The Benefits of The Application of Experience to The Teacher Candidates. Uludag Universitesi Egitim Fakultesi Dergisi, 20(1), 121-143.

Silay, I., \& Gok, T. (2004). A Study on The Problems The Prospective Teachers Face in The Application Schools and Solutions. XIII. Ulusal Egitim Bilimleri Kurultayi, Inonu Universitesi, Malatya, Turkey.

Stewart, V. (2012). A World-Class Education: Learning from International Models of Excellence and Innovation. ASCD Member Book.

Ozel Ihtisas Komisyonu Raporu (2014). Egitim Sisteminin Kalitesinin Arttirilmasi. T.C. Kalkinma Bakanligi.

Tepeli, Y., \& Caner, M. (2014). Teacher Certificate Program Students' Opinions on Teaching Practice. Egitim Bilimleri Araştirmalari Dergisi, 4(2), 313-328.

Toksun, S.E. (2020). Pre-Service Turkish Teachers' Opinions about Teaching Practice. Turkish Studies - Education, 15(4), 2599-2610.

Topkaya, Y., Tokcan, H., \& Kara, C. (2012). Opinions of Prospective Social Studies Teachers' Views About Teacher Practice Course. The Journal of Academic Social Science Studies, 5(7), 663-678.

Yesil, R., \& Caliskan, N. (2006). An Assessment of The Cooperation Process in School Experience-I Course in Teacher Training. Kuram ve Uygulamada Egitim Yonetimi, 46, 277-310. 
Yilmaz, K., \& Kab, I. (2013). Social Studies Teacher Candidates' Thoughts About and Evaluations of School Experience and Teaching Practicum Courses. HUMANITAS, 1, 197-215.

COHE (1998). Fakulte-Okul Isbirligi. Yok/ Dunya Bankasi Milli Egitimi Gelistirme Projesi Hizmet Oncesi Ogretmen Egitimi: Ankara. 